\title{
Investigation on the Physical Characteristics of Raw Wool Fibers in Ethiopia
}

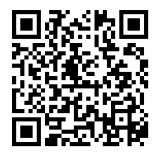

\author{
Erkihun Zelalem* and Sampath VR \\ Ethiopian Institute of Textile and Fashion Technology, Bahir Dar University, Ethiopia
}

Submission: January 31, 2020; Published: February 20, 2020

*Corresponding author: Erkihun Zelalem, Ethiopian Institute of Textile and Fashion Technology, Bahir Dar University, Bahir Dar, 1037, Ethiopia

\begin{abstract}
Ethiopia's economy is primarily based on agriculture ( $46 \%$ of Gross Domestic Product). The Ethiopian textile and apparel industry have grown an average of $51 \%$ over the last five years. Ethiopia's sheep population, estimated to be 25.5 million heads, is found to be widely distributed across the diverse agro-ecological zones of the country. Wool, common name applied to the soft, curly fibers obtained chiefly from the fleece of domesticated sheep and used extensively in textile manufacturing. The fleece of sheep raised for wool is generally shorn once yearly, in the spring or early summer. In regions where the climate is warm throughout the year, shearing may occur twice annually. The value of wool on the market depends primarily on fineness and length of fiber. Strength, elasticity, amount of crimp, and uniformity are also considered. The present study was carried out to investigate the physical properties of raw wool fibers. A total of 24 sheep were used in this study. Samples of fiber were analyzed using standard measurements for wool fiber crimp, tenacity, moisture and amount of trash in the raw wool and comparing the weight of the raw wool to the cleaned wool fiber. Samples are drowning from four different parts of the country and the breeds are menz, tikur, farta and washera. The fineness of wool was coarser based on the microns grading system.
\end{abstract}

Keywords: Crimp; Tenacity; Lint; Fleece; Raw wool

\section{Introduction}

Ethiopia, with a population of 96.6 million is the second-most populous nation in Sub- Sahara Africa after Nigeria. Ethiopia's economy is primarily based on agriculture (46\% of GDP). The government has been determined to diversify the exports with a priority set for strategic sectors like light manufacturing, textile- and garment manufacturing. The Ethiopian government has spearheaded the sector as one of the key priority sectors for the generation of future employment and to realize its aim to enhance foreign currency earnings. This is supported by the creation of various industry policies and incentives to attract foreign direct investors. Keeping in view the current situation of textile industry of Ethiopia, the government is looking forward to taking necessary actions and strategic plans for the future to grant subsidies for the textile sector. Under this strategic plan the textile industry of the country, will have substantial growth in the export of textile yarns and apparel to increase exports projected to $\$ 26$ billion, in addition to the creation of further employment opportunities. All manufacturing industries in textile mills are processing cotton fiber and some synthetic and regenerated fiber and producing woven fabric, knitted fabric and other different products whereby using local and imported raw materials. Ethiopia's sheep population, estimated to be 25.5 million heads, is found widely distributed across the diverse agro-ecological zones of the country [1].

It has been reported that about $75 \%$ of the total sheep population are kept in small scale mixed farms in the highlands, which cover regions of over 1500 meter above sea level and receive over $700 \mathrm{~mm}$ of annual rainfall, while the remaining $25 \%$ are found in the lowlands [2,3]. Wool is a fiber, or modified hair, that grows from the skin of sheep. Because it is formed as a living substance, its growth is regulated by the inherited characteristics of the sheep and by the general condition of the sheep producing it. Therefore, the amount and quality of wool produced can be changed through management, breeding and feeding practices. The individual wool fiber grows from a small depression, known as a follicle, in the skin. Follicles are well supplied with blood vessels, which carry to the fiber the food materials necessary for its growth. Surrounding each wool follicle are two kinds of glands, known as the sweat and sebaceous (wax) glands, which supply protective materials for the fleece. The sweat glands secrete a material, often called sweat salts, which prevents the fibers from being damaged by sunlight. The sebaceous glands secrete wool grease, which forms a protective covering on the fiber and prevents mechanical damage through rubbing. In the past, there 
were many projects has done to improve production of meat, milk and productivity of sheep breed. Early sheep were probably domesticated not for their wool, but rather as a source of food and skins. In Ethiopia the sheep sector is traditionally dominated by small scale sheep breeding and production systems. Farmers lack technical knowledge resulting in low productivity and profitability of the farms. Development strategies for individual agricultural sectors are not implemented (particularly in wool). There are no specialized sheep wool institutions and professional staff supporting sheep sector. Since collection of wool is not organized in many parts of Ethiopian farmers are throwing wool into rivers or set it on fire in open places. The main objective of this thesis is to characterize the physical properties of sheep wool fiber in case of Amhara National Regional State in Ethiopia [4].

\section{Materials and Methods}

The sample were generated from farms sheep and if the sheep is reared in a small-scale enterprise that grouped for breeding and reproductive of animal's center which governed by head of agriculture office. Analyzed virgin wool samples are taken from sheep located in the Amhara regions of different places. Selected sheep are of males and females and four different breeds (menz, washera, farta and tikur). A total of 24 sheep (12 males and 12 females) were used in this study. Selected sheep are of males and females and four different breeds (menz, washera, farta and tikur). Shearing has done from different parts of male and female sheep and mixing properly use core sampling technique by hands. From each breed and sex 50 grams of fleece has been drawn for laboratory samples.
The tested results were analyzed by comparison the significance value of the tested fiber from breed to breed and sex based on International Wool Secretariat [IWS], International Wool Testing Organization[IWTO], Australian wool standards and other wool processing and manufacturing standards. Australia Wool Testing Authority [AWTA] raw wool provides independent and objective wool certification services. AWTA raw wool's major services are sampling, testing and certifying the yield, fiber diameter, vegetable matter content, crimp, moisture and staple strength of tenacity greasy wool before it is sold.

\section{Results and Discussion}

\section{Determination of crimp of wool fiber}

Crimp refers to waves, bends, twists or curls along the fiber length. It is expressed as Crimps per unit length. Some natural fibers are linear; others form two Dimensional or three-dimensional crimps. Crimped fibers tend to have higher elongation than linear fibers. Crimp is an important fiber property affecting fiber cohesion, drafting, bulkiness, processing performance, spinning, yarn quality, fabric handle, comfort and bulk etc. Higher crimp tends to be associated with less entanglement during scouring, lower yarn hairiness and neps and fabric felting shrinkage, but higher noil, yarn irregularity and thin and thick places and spinning end breaks and lower the yarn strength. Higher crimp wools tend to be stiffer than lower crimp wools, which impacts their handling properties (Table 1). High crimp frequency arises from highly curved follicles, and these crimped fibers contain a high proportion of para cortical cells $[5,6]$.

Table 1: Crimp of Wool Fiber in Percentage.

\begin{tabular}{|c|c|c|c|c|c|c|c|c|}
\hline \multicolumn{9}{|c|}{ Breed } \\
\hline \multirow{7}{*}{ Crimp\% } & \multicolumn{2}{|c|}{ Menz } & \multicolumn{2}{|c|}{ Tikur } & \multicolumn{2}{|c|}{ Farta } & \multicolumn{2}{|c|}{ Washera } \\
\hline & Male & Female & Male & Female & Male & Female & Male & Female \\
\hline & 13 & 13 & 18 & 6 & 7 & 12 & 6 & 8 \\
\hline & 6 & 15 & 8 & 10 & 7 & 6 & 5 & 8 \\
\hline & 14 & 11 & 10 & 10 & 11 & 8.5 & 8 & 6.2 \\
\hline & 11 & 9 & 13 & 13 & 9.5 & 9 & 11 & 7.8 \\
\hline & 11.5 & 10 & 10.5 & 9.8 & 8 & 7.5 & 9.4 & 7 \\
\hline Average & 11.1 & 11.6 & 11.9 & 9.76 & 8.5 & 8.6 & 7.88 & 7.4 \\
\hline
\end{tabular}

\section{Determination of tenacity of wool fiber}

Table 2: Tenacity of Raw Wool.

\begin{tabular}{|c|c|c|c|c|c|c|c|c|}
\hline \multirow{3}{*}{$\begin{array}{c}\text { Parameters } \\
\text { Sex }\end{array}$} & \multicolumn{8}{|c|}{ Breed } \\
\hline & \multicolumn{2}{|c|}{ Menz } & \multicolumn{2}{|c|}{ Tikur } & \multicolumn{2}{|c|}{ Farta } & \multicolumn{2}{|c|}{ Washera } \\
\hline & Male & Female & Male & Female & Male & Female & Male & Female \\
\hline $\begin{array}{c}\text { Tenacity (cN/ } \\
\text { tex) }\end{array}$ & 27 & 30 & 15 & 17 & 14 & 15 & 8 & 9.2 \\
\hline Count(Ne) & $31^{\mathrm{s}}$ & $33^{s}$ & $21^{s}$ & $20^{\mathrm{s}}$ & $20^{s}$ & $19^{s}$ & $18^{s}$ & $19^{s}$ \\
\hline
\end{tabular}

Tenacity of wool fiber has done by using the breaking strength of wool fiber and its linear density which measured the

weight of different single wool fiber by using torsion balance and take the length of each fiber summation [7-9] which is illustrated 
in Table 2. We can calculate the spinning count (English count) for comparison based on its linear density [10].

\section{Determination of moisture content of raw wool fiber}

Moisture Content Measurement: The entire samples were preconditioned in a stability chamber for $24 \mathrm{hr}$ at $65 \pm 2 \% \mathrm{RH}$ and $27 \pm 20$ C. The moisture content was determined after obtaining

Table 3: Moisture Measurement the weight of wool dried at 1050C for 20mins on the ETADRY machine and the results showed in (Table 3). Wool fibers have a hygroscopic behavior; it can be the ability of absorbed and give up moisture [11,12]. The normal standards of raw wool fiber moisture content and regain in percentage are around 13.8 and 16.0 respectively. Our results are almost similar within the standard values, but it depends on the structure of the fiber [13].

\begin{tabular}{|c|c|c|c|c|c|}
\hline \multicolumn{7}{|c|}{ Moisture Measurement } \\
\hline \multirow{3}{*}{ Breed } & Sex & Original Mass(gm) & Oven-Dry Mass (gm) & Moisture Regain (MR\%) & Moisture Content (MC\%) \\
\hline \multirow{3}{*}{ Menz } & Male & 25 & 21 & 19 & 16 \\
\cline { 2 - 6 } & Female & 25 & 21.09 & 18 & 15 \\
\hline \multirow{3}{*}{ Fikur } & Male & 25 & 22.1 & 13 & 11 \\
\cline { 2 - 6 } & Female & 25 & 22.23 & 12 & 11 \\
\hline \multirow{3}{*}{ Washera } & Male & 25 & 22.45 & 12 & 11 \\
\cline { 2 - 7 } & Female & 25 & 22.2 & 10 & 9 \\
\cline { 2 - 6 } & Male & 25 & 22.6 & 11 & 10 \\
\hline
\end{tabular}

\section{Scouring the raw wool fleece}

Scouring is a washing process which removes the dirt and the natural grease called lanolin. Unscoured wool is called "wool in the grease" [14]. We can wash the raw wool fiber by using hot water, soap, and alkaline chemicals. I was done by used only hot water and I soaked the wool overnight in cold water, this ensures that it's thoroughly wet through, it already starts removing the dirt, and it can help remove staining too. Take the wool from the cold water and place it into warm water, add hot water to bring this up to temperature, somewhere just above $52 \pm 30 \mathrm{C}$ at 5 minutes [ASTM D 584 and ASTM D 1060]. After soaking I had pull out from the bath and make to drying 105 to $1100 \mathrm{C}$ until the wet removed. Take the weight difference between the raw fleece and the cleaned fiber $[6,15]$. Table 4 showed that the percentages of waste after scouring the raw wool fleece. The above Figure 1 shows that the practical process of trash removal of raw wool fleeces on by scouring processes and the results (Table 4) and the Shirley trash analyzer (for wool) to determine the trash and the lint of the raw wool fiber and results (Table 5).

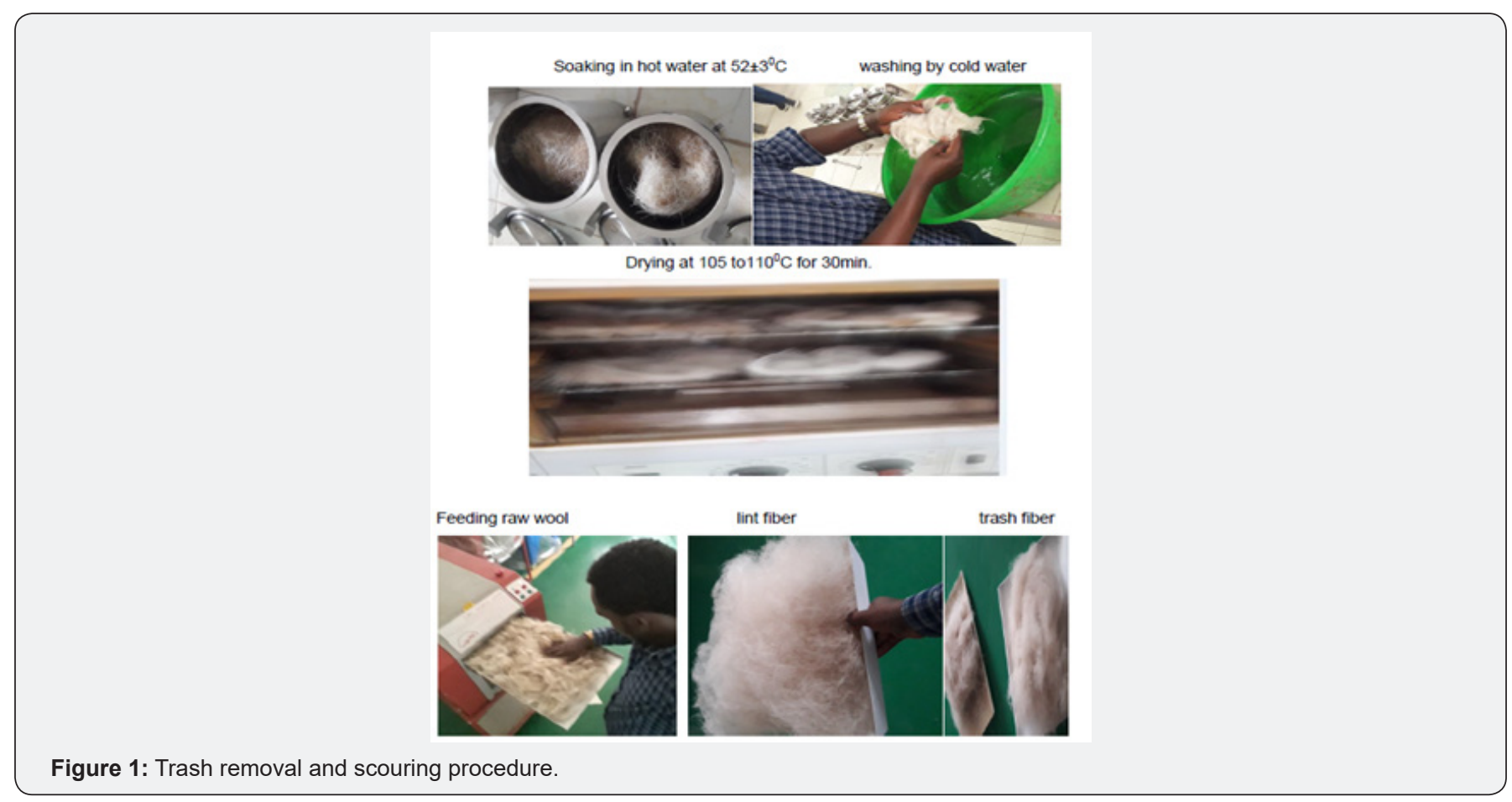


Table 4: Scouring.

\begin{tabular}{|c|c|c|c|c|}
\hline \multirow{2}{*}{ Breed } & \multicolumn{4}{|c|}{ Scouring of Raw Wool Fiber } \\
\cline { 2 - 5 } & Sex & Raw Wool Fleece Weight & Cleaned Fiber Weight & Waste in Percentage \\
\hline \multirow{2}{*}{ Menz } & Male & 12 & 8.4 & $30 \%(40-70) \%$ \\
\cline { 2 - 5 } & Female & 12 & 8.28 & $31 \%$ \\
\hline \multirow{2}{*}{ Tikur } & Male & 12 & 7.36 & $38 \%$ \\
\cline { 2 - 5 } & Female & 12 & 7.9 & $34 \%$ \\
\hline \multirow{2}{*}{ Farta } & Male & 12 & 8.54 & $33 \%$ \\
\cline { 2 - 5 } & Female & 12 & 8.64 & $28 \%$ \\
\hline \multirow{2}{*}{ Washera } & Male & 12 & 8.16 & $32 \%$ \\
\cline { 2 - 5 } & Female & 12 & & $28 \%$ \\
\hline
\end{tabular}

Table 5: Trash and Lint of Raw Wool.

\begin{tabular}{|c|c|c|c|c|}
\hline Breed & Raw Wool Weight(gm) & Total Lint Content(gm) & Total Trash (gm) & Trash Content in \% \\
\hline Menz & 50 & 26 & 13.07 & $26 \%(40-70) \%$ \\
\hline Tikur & 50 & 26.65 & 15.16 & $30 \%$ \\
\hline Farta & 50 & 29.96 & 14.76 & $29 \%$ \\
\hline Washera & 50 & 34.04 & 10.4 & $20 \%$ \\
\hline
\end{tabular}

\section{Determination of trash of raw wool fiber}

MK2 Trash Analyzer/F102/A for cotton /wool model [ASTM D 584, 1060, 1113]. To determine lint, trash and dust content within a sample of wool fiber up to 100 grams. The analyzer uses the carding principle with air separation of lint and nonlint content. The Analyzer Mk2 (Wool Model).To determine vegetable and other foreign matter content in raw wool. Wool tops and waste and preparation of samples for fineness testing. But it does not determine the amount of grease, suits and wax, see in (Table 5), [16,17].

\section{Conclusion}

The results of experiment for determined the physical properties of raw wool fiber involving of Amhara National Regional State in Ethiopia and to compare the properties of different breeds [18-21]. The crimp of menz and tikur breeds is better than the others and the fineness and the tenacity has better. The moisture content and regains has no significance (they are similar moisture properties between them). Raw wool trash is very high when compared to the clean wool fibers. We can use such fibers for the application of rugs, coverings, carpets and other products because of its coarseness [22-25].

\section{References}

1. CSA (Central Statistical Authority) (2013) Agriculture Sample survey. Statistical bulletin. Addis Ababa, Ethiopia.

2. Charles W Hock, Robert C Ramsay, Milton Harris (1942) Microscopic Structure of the Wool Fiber. Journal of Research of the international Bureau of Standards 27: 181-190.

3. Gizaw S, Solomon Abegaz, Barbara Rischkowsky, Aynalem Haile, Ally Okeyo Mwai, et al. (2013) Review of sheep research and development projects in Ethiopia. Nairobi, Kenya International Livestock Research Institute (ILRI), pp. 1-60.
4. (ESGPIP) (2009) Ethiopia Sheep and Goat Productivity Improvement Program. Bulletin No 28, sheep breeds in Ethiopia.

5. Graham P (2003) Wool Technol. Sheep Breed, 51(2).

6. Bunge R, Thomas DL, Nash TG, Lupton CJ (1996) Performance of Hair Breeds and Prolific Wool Breeds of Sheep in Southern Illinois: Wool Production and Fleece Quality. J Anim Sci 74(1): 25-30.

7. Taoufik Harizi, Fatma Abidi (2015) Characteristics of Virgin and Pulled Wool Fibers Used in Tunisian Handmade Carpets. International Journal of Scientific \& Technology Research 4(10): 1-5.

8. Edmunds AR (1990) A Review of New Zealand R\&D on raw wool specification for marketing. In Proceedings of the $8^{\text {th }}$ Int Wool Text Res Conference, New Zealand, pp. 18-27.

9. Baxter BP (2002) Raw Wool Metrology: Recent Developments and Future Directions Processing. Wool Industry Science \& Technology Conference, pp.1-9.

10. T Harzi, Abidi F, Hamdaoui R, Ben Ameur Y (2015) Variation in Fleece Characteristics of Tunisian Sheep. International Journal of Textile Science 4(5): 97-101.

11. Bell (1983) Implications to top makers and wool combers of alternative clip preparation techniques. In Proceedings of the Seminar on Clip Preparation Research, CSIRO Division of Textile Physics and Australian Wool Corporation, Ryde, Australia wool corporation: Ryde Australia, pp. 127-158.

12. (2011) Sampling Wool. IWTO Sampling, SGS Wool Testing Services, Info Bulletin 5.12: 1-2.

13. Anton Z Botha, Lawrance Hunter (2010) The Measurement of Wool Fiber Properties and their effect on worsted processing performance and product quality. Part 1: The objective measurement of wool fibre properties. 42(4): 227-339.

14. Russell BC, Cottle DJ (1993) Sampling variance in sale lots and its influence on test precision. Wool Technology and Sheep Breeding 41(2): 1-127.

15. Dick JL, Sumner RMW (1996) Development of fiber and follicle characteristics related to wool bulk in Perendale sheep over the first year of life. Proceedings of the New Zealand Society of Animal Production 56: 314-318. 
16. International Wool Secretariat (1995) Wool Premiums and Discounts Analysis of Wool Sold at Auction-Third Quarter 1995 Season. Melbourne, Australia.

17. Aylan-Parker J, Mc Gregor BA (2002) Optimizing sampling techniques and estimating sampling variance of fleece quality attributes in alpacas. Small Ruminant Research 44(1): 53-64.

18. Mekuriaw S, Haile A (2014) Genetic parameter estates for growth and reproductive traits of Sheep for genetic improvement and designing breeding program in Ethiopia: A Review. Open Access Library Journal, pp. 1-10.

19. (2009) Advances in wool technology. In: Johnson NAG, Russell IM, Woodhead Publishing in Textiles: Number 72, Woodhead Publishing Limited, UK, pp. 1-212.

20. Solomon Gizaw, Sisay Lemma, Hans komen, Johan A M Van Arendonk (2007) Estimates of genetic parameters and genetic trends for live weight and fleece traits in Menz sheep. Small Rumin Res 70(2): 145153.

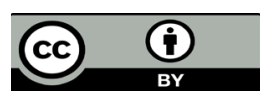

This work is licensed under Creative

Commons Attribution 4.0 Licens

DOI: 10.19080/CTFTTE.2020.06.555686
21. AWTA (2002) Testing the wool clips. Australia Wool Testing Authority Ltd, pp.1-32.

22. Nolan C (1986) Wool Technol Sheep Breed 34(2).

23. Scobie DR, Bray AR, Merrick NC (1998) Medullation and average fibre diameter vary independently in the wool of Romney sheep. New Zealand Journal of Agricultural Research 41(1): 101-110.

24. Nosratollah Taherpour, Mahnaz Salehi, Farhad Mirzaei (2012) Evaluation certain environment factors on wool characteristics of Arabi sheep breeds. Open Journal of Animal Sciences 2(1): 11-14.

25. (2011) Fibre Length. SGS Wool Testing Services, Info Bulletin 1.3: 1-2.

\section{Your next submission with Juniper Publishers} will reach you the below assets

- Quality Editorial service

- Swift Peer Review

- Reprints availability

- E-prints Service

- Manuscript Podcast for convenient understanding

- Global attainment for your research

- Manuscript accessibility in different formats

( Pdf, E-pub, Full Text, Audio)

- Unceasing customer service

Track the below URL for one-step submission https://juniperpublishers.com/online-submission.php 